\title{
Sequence Stratigraphic Interpretation of XY-Field Onshore Niger Delta Basin Nigeria
}

\section{${ }^{1}$ OKPALA, CE; *2OSISANYA, OW; ${ }^{3}$ IGHRAKPATA, FC; ${ }^{4}$ SALEH, AS; ${ }^{5}$ IBITOYE, TA}

\author{
${ }^{I}$ Department of Earth science, Federal University of Petroleum Resources Effurun, Delta State. \\ ${ }^{* 2}$ Department of Physics, University of Benin, Benin City, Edo state, Nigeria \\ ${ }^{3}$ Department of Physics, College of Education, Edjeba, Warri South, Delta State. \\ ${ }^{4,5}$ Department of Petroleum Engineering and Geosciences, Petroleum Training Institute, Effurun, Nigeria. \\ *Corresponding Author Email: wasiu.osisanya@ uniben.edu
}

\begin{abstract}
Wireline logs and biostratigraphic data were integrated to attempt the sequence stratigraphy of "XY field" onshore Niger Delta Basin which revealed three depositional sequences. Four sequence boundaries and three maximum flooding surfaces dated $(17.7,16.7,15.5$, and $13.1 \mathrm{Ma})$ and $(17.4,15.9,15.0 \mathrm{Ma})$ respectively were identified in both Wells. The delineated sequences comprised Lowstand Systems Tracts (LST), Transgressive Systems Tracts (TST) and Highstand Systems Tracts (HST), which reflect depositional systems deposited during different phases of base level changes. The sands of LST and HST show good reservoir qualities while the shales of the TSTs could form potential reservoir seals. Integration of lithofacies and biofacies data suggests that the depositional environments ranges from transitional to Outer Neritic environment.
\end{abstract}

\section{DOI: https://dx.doi.org/10.4314/jasem.v25i12.2}

Copyright: Copyright $(2021$ Okpala et al. This is an open access article distributed under the Creative Commons Attribution License (CCL), which permits unrestricted use, distribution, and reproduction in any medium, provided the original work is properly cited.

Dates: Received: 22 August 2021; Revised: 17 September 2021; Accepted: 06 October 2021

Keywords: Sequence Stratigrapy, Wireline logs, Biostratigraphy, System Tracts, Niger Delta.

For several decades, majority of the geoscientific research carried out in the Niger Delta Basin, focused mainly on the lithostratigraphy and tectonic framework of the area which is why very few published research work on the sequence stratigraphy of wells in this area exist. However, with increasing interest in the Niger delta basin as a result of its great economic potential, there is need for more detailed understanding of the sequence stratigraphy of the existing wells to enhance correlation between these wells thereby reducing the risks involved in hydrocarbon exploration which may arise as a result of insufficient data. The integration of sequence stratigraphy and high resolution biostratigraphy framework is fundamental in the design of an effective exploration strategy to reduce the complexities and enhance the degree of reliability and precision in the stratigraphic mapping of the Niger Delta. (Abraham et al., 2020) The aim of this research work is to carry out a sequence stratigraphic interpretation of "XY field" within the onshore Niger Delta Basin, using well log and biostratigraphic data to interpret the depositional environments of the benthic foraminifera and palynomorphs recovered from the Well log and age date them. Sequence stratigraphy is a methodology that provides a framework for the elements of any depositional setting, facilitating a paleogeographic reconstruction and the prediction of facies and lithologies away from control points. This framework ties changes in stratal stacking patterns to the responses to varying accommodation and sediment supply through time. Stratal stacking patterns enable determination of the order in which strata were laid down, and explain the geometric relationships and the architecture of sedimentary strata. The sequence stratigraphic framework also provides the context within which to interpret the evolution of depositional systems through space and time. This analysis is improved by integration of process sedimentology with an understanding of the geometries and scales of the component depositional elements (Sprague, et al., 2002). Over the past fifteen years, this approach has been embraced by geoscientists as the preferred style of stratigraphic analysis, which has served to tie together observations from many disciplines. In fact, a key aspect of the sequence stratigraphic approach is to encourage the integration of data sets and research methods. Blending insights from a range of disciplines invariably leads to more robust interpretations and, consequently, scientific progress. Thus, the sequence stratigraphic approach has led to improved understanding of how stratigraphic units, facies tracts, and depositional elements relate to each other in time and space within sedimentary basins. A sequence stratigraphic framework may consist of three types of sequence stratigraphic unit, namely sequences, system tracts, and parasequences. (Catuneanu, 2006). For a successful and detailed sequence stratigraphy study, integration of different disciplines and data as well as adequate knowledge of different environmental parameters are highly required. (Figure 1) 


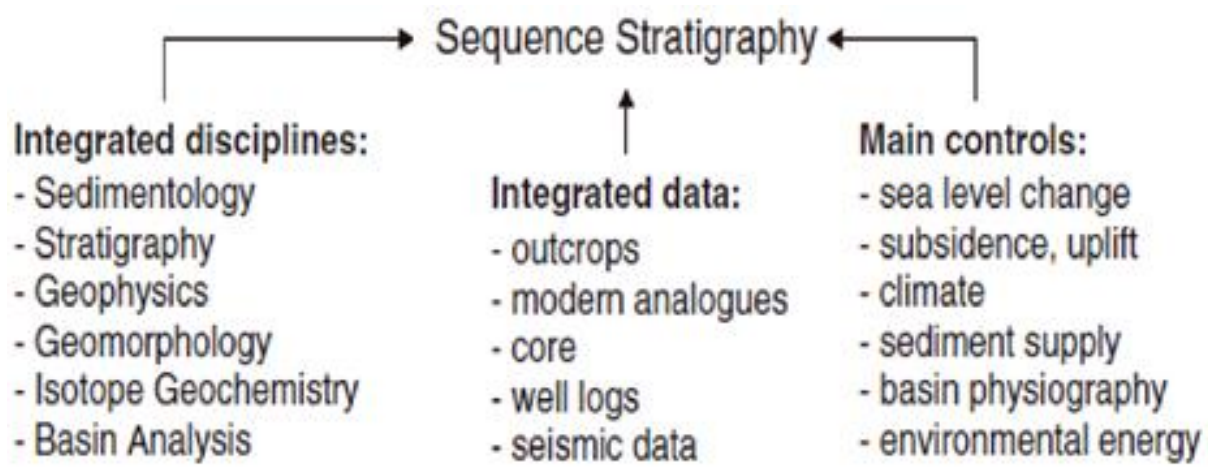

Fig 1: Sequence stratigraphy in the context of interdisciplinary research (Catuneanu, 2006)

Biostratigraphy simply involves the differentiation of rock units based on their fossils content. The three microfossils groups which are of particular importance to hydrocarbon exploration include: foraminifera, palynomorphs and calcareous nannofossils. The benthic foraminifera were used in paleoenvironmental analysis to determine the oceanic depth at which each sequence was deposited (paleobathymetry) as they are restricted to certain environments while the planktic foraminifera were used in age dating as they provide less information about environments of deposition since they lived floating in the water column. Unlike foraminifera which are restricted to purely marine environments, palynomorphs can be found in both marine and continental environments. Hence, they serve as very useful indicators of paleoenvironment of deposition; while the pollen and spores can be found in continental and shallow marine environments, dinoflagellate cyst are more abundant in deep marine environments. The zones of maximum abundance and diversity of these microfossils were used to identify the condensed sections which house the maximum flooding surfaces while the zones of least abundance and diversity of the fossils were used to delineate the sequence boundaries. (Haq et al,. 1988)

Geology of the study area: The analyzed wells are located within the onshore Niger Delta Basin. The study area contains an extensive wedge of Cretaceous to recent sediments. The basin has been of much geological interest as it serves as a source of hydrocarbon exploration. A Delta is a discrete shoreline protuberance formed at a point where a river enters an ocean or other body of water. Coarser sediments (sands) tend to be deposited near the mouth of the river while finer sediments are carried seaward and deposited deeper water. The form and character of the sediment is determined by the predominant sedimentary processes of fluvial, wave and tidal actions. The Cenozoic Niger Delta overlies (Figure 2) an area that is over $256,000 \mathrm{~km} 2$. It is the youngest of the three large sediment bodies that filled the aulacogen formed after the separation of the African and South American plates. It was initially built out over a transgressive Paleocene prodelta as river dominated lobes which later coalesced and became high-energy, wave-dominated, and tide influenced depobelts. The progradation was facilitated by rapid sediment accumulation that substantially exceeded the rate of subsidence. The Cenozoic Niger Delta is situated at the intersection of the Benue Trough and the South Atlantic Ocean where a triple junction developed during the separation of the continents of South America and Africa in the late Jurassic (Whiteman , 1982). The Niger Delta started to evolve in early Tertiary times when clastic river input increased (Doust et al,. 1989). Generally, the delta prograded over the subsidizing continental-oceanic lithospheric transition zone, and during the Oligocene spread onto oceanic crust of the Gulf of Guinea. The weathering flanks of out-cropping continental basement sourced the sediments through the BenueNiger drainage basin. The delta has since Paleocene times prograded a distance of more than $250 \mathrm{~km}$ from the Benin and Calabar flanks to the present delta front (Evamy et al., 1978). Thickness of sediments in the Niger Delta averages $12 \mathrm{~km}$ covering a total area of about $140,000 \mathrm{~km} 2$. Hence, exploration or reservoir analysis are accurately predicted and delineated, the spatial and depth distribution of subsurface geologic facies and the capacity to discriminate the fluids saturating the reservoirs (oil, gas or brine) and possibly quantifying such via sequence stratigraphy studies. (Aminu and Olorunniwo, 2012). 

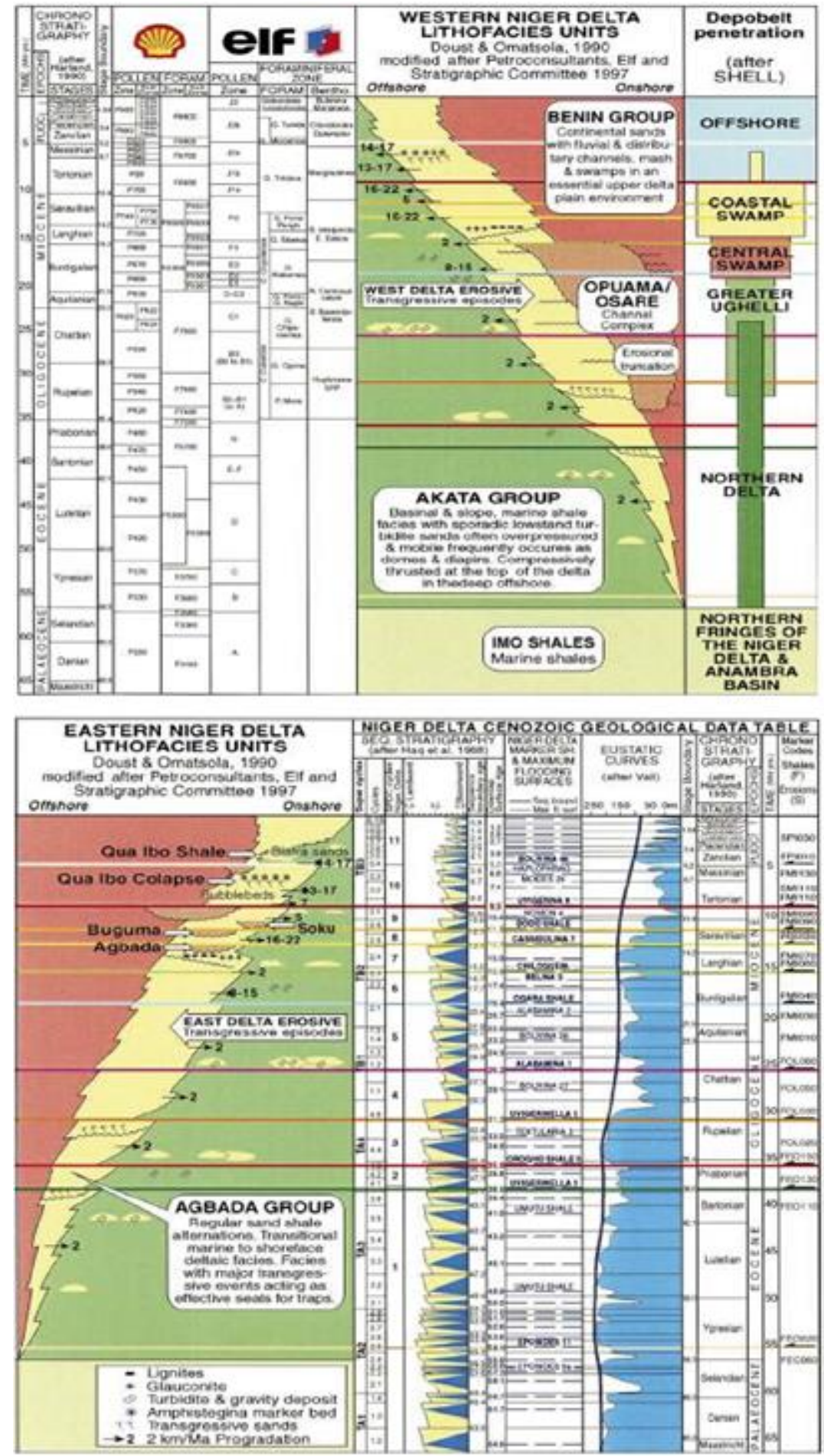

Fig 2: Stratigraphic data sheet of the Niger Delta. Source: Adapted from Reijers (2011).

\section{MATERIAL AND METHODS}

The interactive Schlumberger petrel software package (2013 version) was used for the analysis of well log data, while the stratabug software was utilized in the analysis of the biostratigraphic data. The workflow algorithm adopted for this study is shown below (Figure 3). The procedure followed in this work involved recognition of patterns that reflect changing water depths and distribution of accumulated sediments within depositional cycles as stated by
(Armentrout et al., 1993). Logs are first used to define possible coarsening or fining upward intervals within forestepping, vertically stacked, or backstepping succession (Rider, 1990). These are then integrated with biostratigraphical data and recovered from Well $\mathrm{X}$ and Well $\mathrm{Y}$ for dating and determination of depositional environments. 


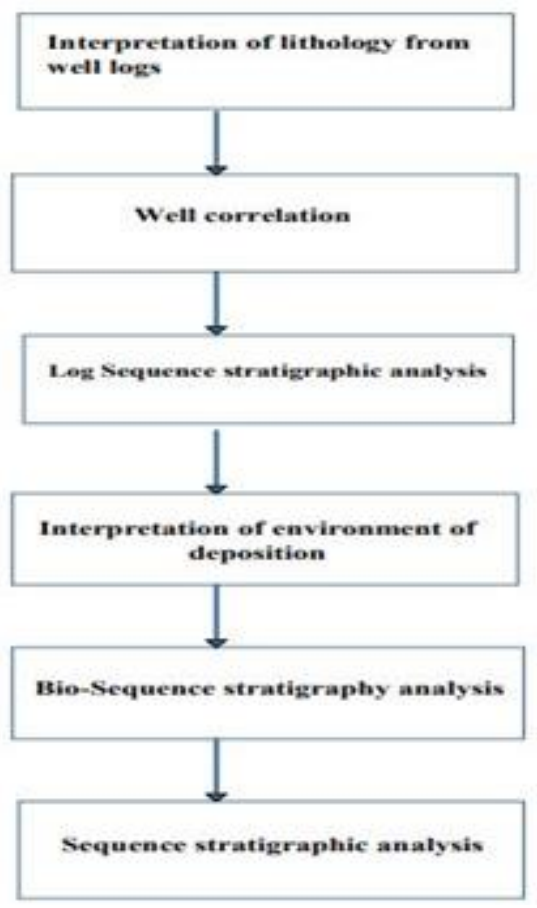

Well log-sequence Stratigraphic Analysis: Wireline logs play an important role in the analysis of the subsurface. Analysis and interpretation of $\operatorname{logs}$ facilitate lithology and depositional environment identification. These can be correlated with the seismic reflection, thus linking seismic facies, rock properties and sedimentology facies. The methods for environment diagnostic approach by (Cant, 1992), and (Rider, 1990) were adopted for the study. The well logs were also interpreted to delineate the stratigraphic tops that represent time stratigraphic surfaces within the study area. The log types utilized during the course of this work are the gamma ray log and resistivity log. Log trends are observed and equated with trends in depositional energy and thus with the patterns of sedimentary fill. A number of distinctive trends are recognized on the wireline logs. These trends are described from their gamma ray expression. The typical log trends are illustrated in Figure 4 (Emery, 1996).

Fig 3 Work flow chart

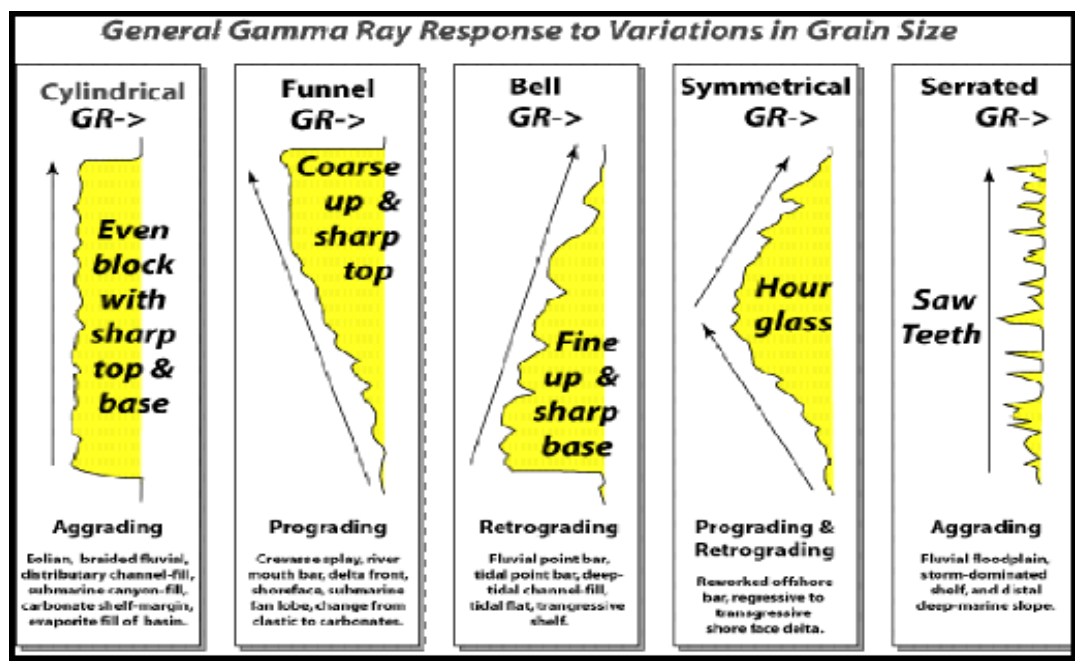

Fig 4: General gamma ray response to variations in grain size (modified from Emery, 1996)

Lithology Interpretation from Well Logs: The first step is the identification of the different lithofacies using the composite well logs. The gamma ray was used to identify the lithologies of the formation penetrated. Shales or clay minerals commonly have relatively high gamma radioactive response and so gamma ray logs are subsequently use to infer depositional energy. The maximum value corresponds to the shale baseline while the minimum value corresponds to the sand baseline. Sand lithology was painted yellow, while the shaly lithology was painted grey for easy identification and thickness evaluation using the petrel software. The scale of the gamma ray log ranges between 0-150 API. High API values indicate shale while low value is sand. Deflections of the gamma ray log to the right and left is interpreted as shaly sand formation respectively.
The upper part of the sequences across well $\mathrm{X}$ and well $\mathrm{Y}$ displays thicker sand intervals than shale and a coarsening upward trend. At the lower part of the wells (below 5600ft), shale thickness increases relatively to sand interval. Within the logged intervals, the lithology is dominated by alternating sand and shale. (Figure 5)

Well Correlation: This was carried out by the importation and loading of the ASCII data into Schlumberger Petrel software (2013 version). It is from here that well log correlations were loop-tied to assure consistency. Well logs from well X and well Y were correlated to determine stratigraphic units that are equivalent in lithology (Figure $6 \& 8$ ). Correlation was done to determine lateral continuity or 
discontinuity of facies, hence aiding reservoir studies in the well field. Also, correlation was also carried out based on the identification of stratigraphic surfaces and systems tract across the two study wells. The gamma ray log enables shapes to be identified such as funnel, blocky (box car trend or cylindrical trend) and bell shapes (Figure 4). A bell shaped log indicates increasing clay content (fining upward trend) which denotes an upward increasing gamma ray value and characteristics of fluvial deposits to transgressive facies. It also reflects upward decreasing depositional energy i.e. backstepping/ retrograding shoreline (Figure 4) (Emery, 1996). The fining upward trend predominates within meandering or tidal channel deposits. A funnel shaped log motif indicates decreasing clay content (coarsening upward trend) and shows an upward decrease in gamma reading, which indicates a deltaic or prograding environment. It reflects upward increasing depositional energy. The sand can reflect delta lobes or near shore to coastal plain transition This upward decrease in the gamma reading can generally be seen in both the sand baseline and the shale baseline. The coarsening upward trend relates to an upward transition from shale-rich to shale free lithologies. A cylindrical log motif (blocky or box car) implies relatively constant energy level during continued deposition. It indicates fluvial, estuarine or shore face sands. Agradational trend or boxcar pattern are sharp-base low gamma units with an internally relatively constant gamma reading. A sharp-based low gamma unit with an internal constant gamma reading is typical of sands interbedded with shales. Serrated nature of logs suggests the presence of intercalations of thin shale in sand body. The second step is the use of $\log$ shapes and responses for identification of system tracts, sequence boundaries and maximum flooding surface based on the criteria discussed by (Vail and Wornardt, 1992).

Recognition of system tracts, and key surfaces on well logs: The basic procedure involves identifying the maximum flooding surface (MFS) on the electronic $\operatorname{logs}$ followed by the identification of sequence boundary in between the two maximum surfaces. After this, proper analysis of the system tract is carried out.

Maximum Flooding Surface (MFS): The maximum flooding surface (MFS) is marked by lowest resistivity and highest gamma ray reading. It caps the transgressive system tracts and represents the most land ward transgression of the shoreline. It is also delineated from the high abundance and diversity of microfossils.

Sequence Boundaries $(S B)$ : The sequence boundaries (SB) tends to lie directly beneath the sand sized sediment fill of depressions on eroded and incised surface and over the prograding clinoforms of highstand system tract (HST). The identification of sequence boundaries depends on the environment of deposition. For instance, in the neritic environment, the typical log pattern is an aggradational log pattern that overlies an interbedded log pattern making abrupt shallowing. After the key candidate stratigraphic surfaces are picked and marked on the log section, the systems tracts interpreted by the parasequence stacking patterns and nature of the systems tracts boundaries are delineated. Each systems tract has its distinctive log character.

Lowstand system tract (LST): This is the lowermost systems tract. It lays directly on type 1 sequence boundary. If the lowstand systems tract is deposited in a basin within a shelf break, it can be subdivided into three separate units; a basin floor fan, a slope fan and a lowstand wedge (Van Wagoner et. al., 1988).

Basin floor fan (BFF): This is characterized on the gamma ray and resistivity logs by a blocky pattern (Figure 6) with relatively few breaks (unamalgated turbidite sand). It contains massive turbidite sand with the upper boundary characterize by hemi pelagic shale of channel over bank apron facies which forms a minor condensed section associated with peak abundance and diversity of deep water fauna. One of the best criteria for recognizing basin floor fan is to confirm bathyal or deeper paleowater depth. This could be achieved through biofacies analysis.

Slope fan:_This is characterized by cresentric shape in individual level channel units with finning upwards of individual channel levee. The slope fan overlies the basin floor fan and is made up of mass flows and turbidite channel-over bank deposits (Vail, 1987).

Lowstand prograding wedge: This is characterized by an overall coarsening upward pattern, which is commonly called "inverted Christmas tree" pattern on gamma ray logs. It rests directly on the underlying slope fan complex.

Transgressive system tract: This is characterized by finning upward (backstepping) pattern which persists vertically till the maximum flooding surface is reached on the logs

Highstand system tract (HST): This is above the maximum flooding surface and begins with a coarsening upward pattern that predominantly forestepping or building basinward on the gamma ray log.

Biostratigraphic analysis: The biostratigraphic data is an indispensable tool in sequence stratigraphic analysis. The bio-facies data information of Well $\mathrm{X}$ and Well Y was provided and integrated with the Well $\log$ data provided for this work. Foraminifera was used as shale makers as they are index fossils. The benthic foraminifera (bottom dwellers) are suitable for depositional environmental reconstruction while the planktonic forams (floaters) are favorable for correlations. The Niger Delta fauna and pollen 
zonation were employed in the identification of sequence boundaries (SB) and maximum flooding surface with the aid of the Niger Delta chronostratigraphic chat. The maximum flooding surface is recognized (MFS) is recognized by maximum abundance of microfossils, which coincide with deep water environment. The Niger Delta Cenozoic cycle is used in this work to deduce the ages of the maximum flooding surfaces ant the sequence boundaries. The identification of the key surfaces (maximum flooding surfaces and sequence boundaries) using the abundance of these microfossils; the microfossil abundance peaks within the identified depositional sequences correspond to the maximum flooding surfaces while the microfossil abundance minima correspond to the sequence boundaries. This information was then tied to the key surfaces as well as the systems tracts (lowstand systems tract, transgressive systems tract and highstand systems tract) that have been identified with the gamma-ray log after which the surfaces were dated using the zonation scheme of (Haq et al,. 1988) in association with the ages of the marker fossils obtained from the Wells.

The delineated MFSs and SBs which were identified on the well logs were dated with marker fossils ( $\mathrm{P}$ and F zones) and by correlation with the Niger Delta Chronostratigraphic Chart. Relative ages of the surfaces mapped in well $\mathrm{X}$ and well $\mathrm{Y}$ were determined using the provided biostratigraphic data.

Delineating Paleoenvironment: Paleoenvironment was interpreted using the lithological characteristics including Well log signatures, sand/shale ratios, and textural attributes of sand. Also, the study of paleoenvironment was aided using benthic foraminifera.

Age Characterization: The ages of the wells were determined from the foraminifera and palynormorph abundance and diversity chart. Foraminifera and palynomorph zones were established for this purpose. The ages of the sequence stratigraphic surfaces delineated in this study were obtained from SPDC chronostratigraphioc chat. $\mathrm{P}$ and $\mathrm{F}$ zones established from the biostratigraphic data.

\section{RESULT AND DISCUSSION}

The stratigraphic column of the studied wells was divided into three (3) lithofacies, namely: (1) Coarse Grained Sandstone Facies; (2) Shaly Sandstone facies; (3) Shale facies. (Figure 5). The coarse grained sandstone facies was characterized by a blocky and a funnel shape. The sand units are locally separated by thin lens of shale and lack marine fauna. This was found above depth $5680.2 \mathrm{ft}$ in well $\mathrm{X}$ and were correlated at depth $5800 \mathrm{ft}$ on well Y. This facie is interpreted as fluvial channel deposits based on these characteristics. These channel deposits represent deposition in a coastal plain setting landward during regression. The blocky log pattern is common in the incised valley fills (Figure 5). The Shaly-Sandstone facies is characterized by the predominance of finemedium grained sandstones and shale interbeds. It consists predominantly of bell to blocky shaped pattern certain intervals (7000-5800 ft) about $1200 \mathrm{ft}$ thick, on well $\mathrm{X}$ and (7350-5600 ft) about $1750 \mathrm{ft}$ thick on well Y. Biofacies data revealed that the intervals exhibited low abundance and low diversity of foraminifera found within the transitional to Inner Neritic depositional environment. The Shale facies identified is predominantly composed of shale units indicating a retrogradational parasequence pattern during transgression of sea level. This facie interval occur at depth $7604.86905 .4 \mathrm{ft}$ (about $699.4 \mathrm{ft}$ thick) on well $\mathrm{Y}$ and was correlated with well $\mathrm{X}$ at interval 7617.4-7012.1 ft (about $605.3 \mathrm{ft}$ ). The facies also exhibited high abundance and diversity of foraminifera particularly those of Outer Neritic (ON) de-positional environments. The unit is interpreted as offshore deposits.

Log Sequence Stratigraphy: The log sequence stratigraphy of the two wells was done after lithological interpretation based on gamma ray log signatures. For correlation, the focus was on mapping stratigraphic surfaces mainly the sequence boundaries (SBs) and maximum flooding surfaces (MFSs) of the same geologic age defined across the wells, as well as the identification of systems tracts with the aid of the depositional sequence model. These surfaces were identified based on the abrupt change in gamma ray $\log$ signature. Four sequence boundaries and three maximum flooding surfaces were identified across the wells (Figure 7). Sequence Boundaries (SBs) were recognized in areas of low faunal abundance and diversity or absence of known bio-events, which corresponded to low Gamma Ray, high Resistivity, responses within the shallowing section. Candidate Sequence Boundaries were identified at the base of thickest and coarsest sand units between two adjacent Maximum Flooding Surfaces, which naturally coincided with the shallowest environments associated with the least foraminiferal abundance and diversity or complete absence of foraminifera. The base of a progradational stacking pattern was also used to define a Sequence Boundary (SB).

Bio-Sequence Stratigraphy: The stratigraphic intervals studied in well $\mathrm{X}$ and well $\mathrm{Y}$ were characterized or subdivided based on their foraminifera contents (planktics and benthics). This was more reliable in correlating strata and dating sequences. The total planktic foraminifera abundance in well $\mathrm{X}$ is moderate, but the total benthic foraminifera abundance found in the same well is high in contrast to the planktic foraminifera. Results of foraminifera analysis showed that well $\mathrm{X}$ is very rich in calcareous benthic and low in planktic foraminifera but very low in arenaceous benthic foraminifera. The population and diversity of the benthic and planktonic foraminifera 
were used for environmental and paleobathymetric interpretation, since they possessed the ability to narcotize ,paralyzed by means of toxins. The biozone records obtained from the wells were the palynological and foraminiferal zones popularly referred to as the $\mathrm{P}$ and $\mathrm{F}$ Zones.
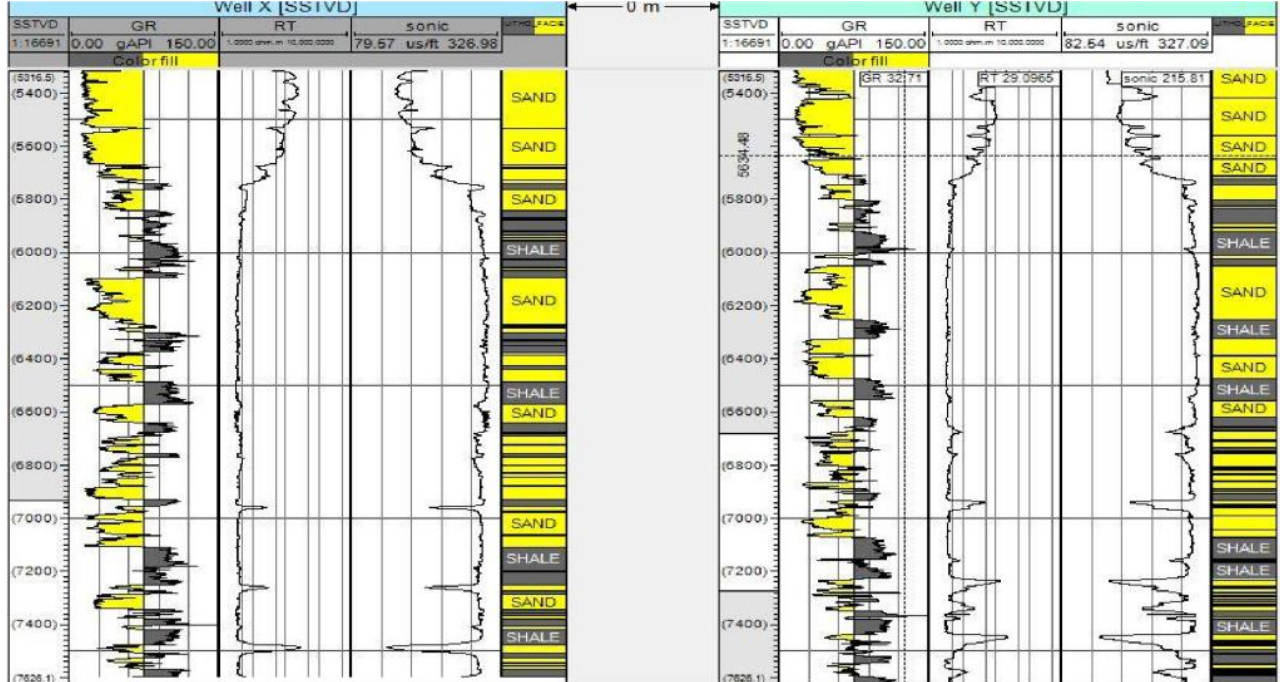

Fig 5: Sand/shale lithologies with the stud(y) wells delineated from gamma ray log

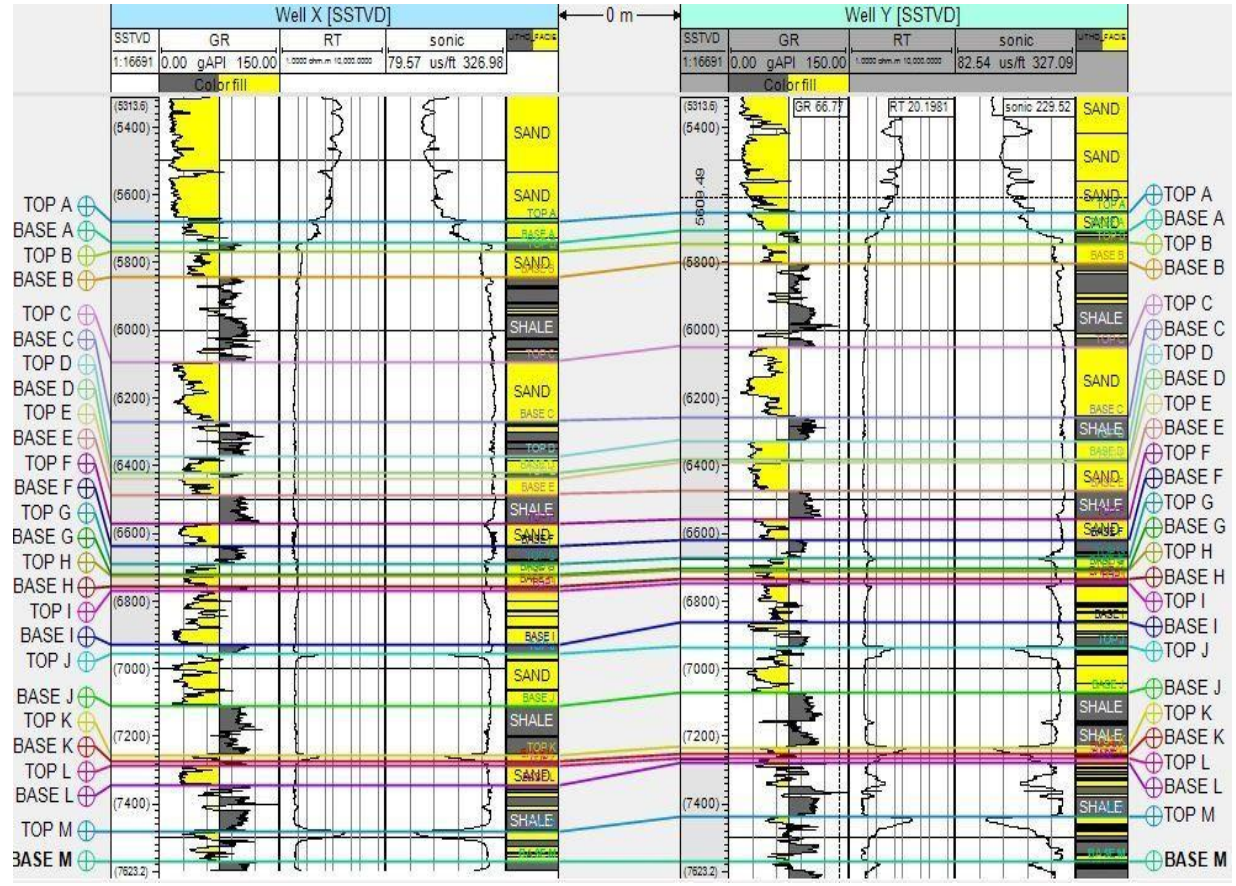

Fig 6: Litho-correlation across Well $\mathrm{X}$ and Well $\mathrm{Y}$

Paleoenvironment of deposition: Inference of the paleodepositional environment of the studied wells was made based on the foraminifera distribution; paleobathymetry interpreted from the benthic foraminifera assemblages and lithologic description of the wells. Gamma Ray Log values and signatures (fining and coarsening upward signatures) and the biofacies data helped in determining depositional environments of the different rocks units in the studied wells. At the upper boundary of the LST is an erosional surface representing initial marine incursion landward within the TST. This was identified in all the wells as an initial deepening signature. During the HST, the sea-level rises decreased and are characterized by initially aggradational deep sea shales that grade into intervals of shallowing upwards (Figure 8). Inner Neritic biofacies are generally occur within shale with occasional sandy intervals. The biofacies is characterized by the common occurrence of Ammonia beccarii, Florilus atlanticus, Floriluscostiferum, Lenticulina inornata, Heterolepa pseudoungeriana, Heterolepa floridana,

Cribroelphidium gunteri, Cancris auriculus, Quinqueloculina spp., Poritextularia panamensis, Spiroplectamina wrightii, Bolivina scalprata miocenica, Marginulina costata, Epistominella vitrea, Hanzawaia strattonii, and Cibicorbis inflata. 
The Middle Neritic environment characteristically contains fine to very fine-grained sands and shale. The rate of deposition is generally slow. The dominant taxa include: Cibicidoides pseudoungerianus, Cibicidoides crebbsi, A. crassum, Haplophragmoides narivaensis, Haplophragmoides compressa, Cibicides lobatulus, Brizalina aenariensis, Eponides eshira, Eponides pseudoelevatus, Marginulina raphanus, Bolivina mandoroveensis,

The Outer Neritic biofacies is characterized by a distinctive benthonic foraminiferal assemblage that is generally absent from other environments. The dominant species include: Bulimina marginata, Buliminella apiculata, Cassidulina carinata, Epistominella exigua, Trifarina angulosa, Nonion centrosulcatum, Cyclammina minima, Cyclammina cancellata, Saccammina complanata, Ammodiscus glabratus, Uvigerina subperegrina, Uvigerina gallowayi, Bolivina retiformis

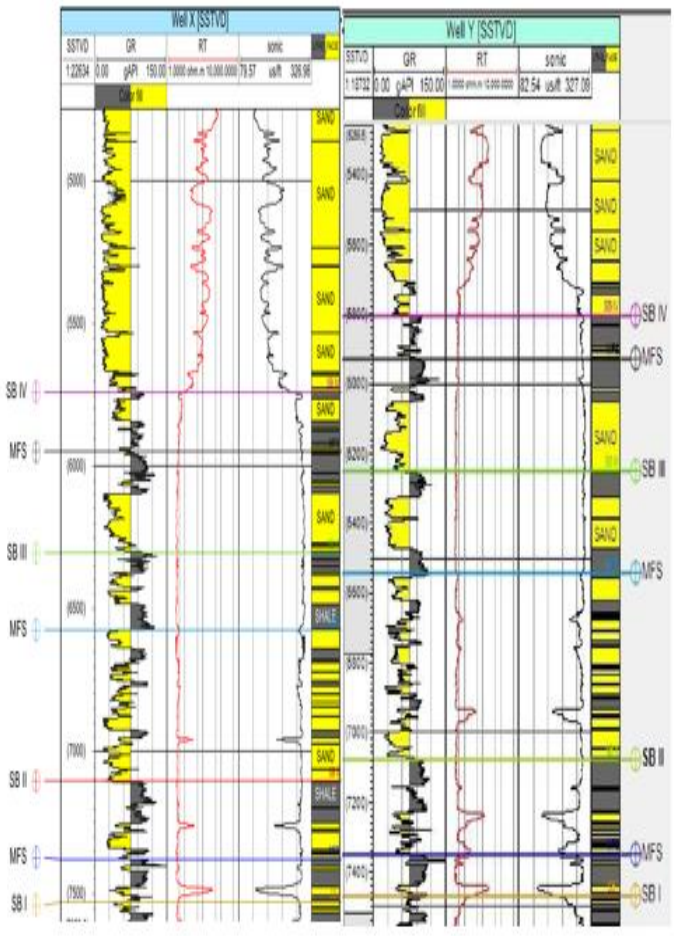

Fig 7: Maximum Flooding Surface and Sequence Boundary interpreted on Well X and Well Y

Fossil Assemblages: Fossils assemblages used to interpret the various water depths (paleobathymetry) of the sediments penetrated by the studied wells include the following:

Shallow inner neritic: Globigerina sp., Uvigerina sp., Bolivina sp., Alabamina sp.

Inner neritic: Cibicides sp., Eponides sp., Triloculina sp.,

Middle neritic: Verneuilina sp., Trochammina sp., Anomalina sp., Trochamminoides sp.

Outer neritic: Globigerinoides $s p$.

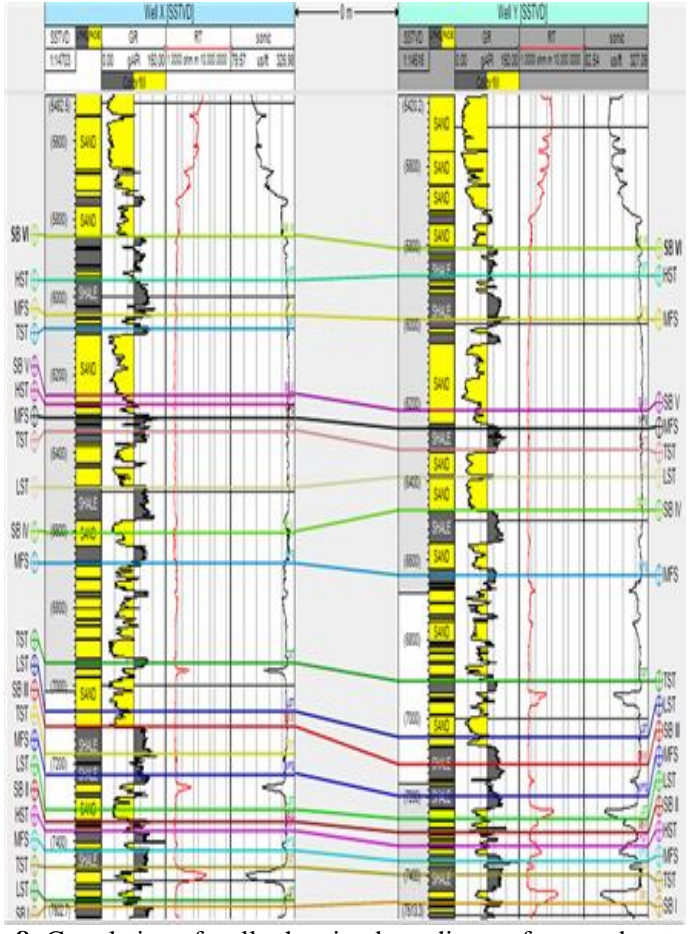

Fig 8: Correlation of wells showing bounding surfaces and systems tracts across well $\mathrm{X}$ and well $\mathrm{Y}$

The inference of the paleobathymetry of intervals 4780, 4820, 4860, 4900 and $4940 \mathrm{ft}$ from well $\mathrm{X}$, and intervals $5700-3590 \mathrm{ft}$ from well $\mathrm{Y}$ as non-marine is based on the following criteria: The intervals are completely barren of microfauna or containing very few benthic and planktic foraminifera like Textularia sp., Quinqueloculina sp., Globigerinoides obliquus and Globigerina glutinata. Rather palynomorph forms such as the Verrutricolporites rotundiporis and Belskipollis elegans, found at intervals 4440-3920 ft and 5426-4508 ft were recovered respectively. The intervals are characterized by fine-medium grained coarse-grained sand. The inference of the paleodepth of these intervals 4800-1400, 6100-5000, 6700-6200, $8600-8400,9000-8760,9400,1000-9800 \mathrm{ft}$ on well X and 7400, 8400, 9500-9400 ft on well $\mathrm{Y}$ as inner neritic is based on the following recognition: The population count of calcareous benthic foraminifera is higher than that of planktic but barren or contains very few arenaceous benthic foraminifera. The average planktic/benthic is low. The indicator fauna found here are Cibicides boueanus, Eponides umbonatus, Triloculina trigonula and Nonion sp. The lithology is characterized by fine-medium-grained sand. The inference of the water depth of these intervals 6200$6000,6700-6250,9000-6800 \mathrm{ft}$ on well $\mathrm{X}$ as inner neritic to middle neritic is based on the following findings: (1) There is an increase in the population of the planktics and increased in species diversity. Also planktic/benthic ratio is increased. Very few or barren of arenaceous benthic foraminifera is observed but high abundance and diversity of calcareous benthic foraminifera. (2) The occurrence of the typical foraminifera taxa from inner, middle and outer neritic 
such as Textularia agglutinans, Triloculina trigonula, Nionionella sp., Globigerina glutinata, Alabamina sp. (3) The lithology is composed of shale and shaly-sand.

Sequence Stratigraphic analysis: This involved the identification of candidate MFSs and sequence boundaries from the biofacies plots and support their candidature through delineation using wireline logs.

Maximum Flooding Surface (MFS): The first maximum flooding surface (MFS1) identified was dated 17.4Ma using the marker specie Cassigerinella 1 which occurred at a depth interval of $7250 \mathrm{ft}$ in Well $\mathrm{X}$ and 8870in Well $\mathrm{Y}$.

The second Maximum Flooding Surface (MFS2) recognized in both wells (Figure 9 and 10) was dated 15.9 Ma respectively using the Niger Delta Chronostratigraphic Chart, a regional marker, Chiloguembelina 3 and the occurrence of the event within F9500 zone. This MFS occurred at a depth interval of $6520 \mathrm{ft}$ in Well X and $6483 \mathrm{ft}$ in Well Y.

The third Maximum flooding surface (MFS3) was recognized using the marker specie, Bolivina $25 /$ Uvigerina 5, which occurred at a depth of $6100 \mathrm{ft}$ in well $\mathrm{X}$ and was dated to be $15.0 \mathrm{Ma}$. The same MFS3 was recognized hence, correlated with well $\mathrm{Y}$ at a depth of $5830 \mathrm{ft}$ found within F9500 zone.

Sequence Boundary (SB): The oldest sequence boundary (SB1) identified was dated 17.7 Million years (Ma) which underlies the MFS1 and was based on its relative position in the stratigraphic sections and with reference to the Niger Delta Chronostratigraphic Chart (Figure 9). This erosional surface occurred at a depth interval of $7500 \mathrm{ft}$ in Well X and $8750 \mathrm{ft}$ in Well $Y$. The second sequence Boundary (SB2) identified in the well $\mathrm{X}$ was dated $16.7 \mathrm{Ma}$ which occurred at a depth of $6730 \mathrm{ft}$ using the marker specie, $L D O$ Crassoretitriletes vanraadshooveni (17) found within the P680 zone. The surface represent a substantial erosional surface defined before the MFS2 of $15.9 \mathrm{Ma}$ on both well $\mathrm{X}$ and well Y. This SB1 was recognized and correlated with well Y at a depth of $7400 \mathrm{ft}$.

The third sequence boundary (SB3) for well $X$ and well $\mathrm{Y}$ was based on its relative position in the stratigraphic sections and with reference to the Niger Delta Chronostratigraphic Chart. It was dated 15.5 Ma. This surface occurred at depth interval of $6220 \mathrm{ft}$ in well $\mathrm{X}$ and was correlated to a depth interval of 6380 $\mathrm{ft}$ in Well Y. SB4 for both wells was dated $13.1 \mathrm{Ma}$ using the marker Interval below base rich Belskipollis elegans found at a depth interval of 5700 and $5519 \mathrm{ft}$ respectively within the $\mathrm{P} 740$ zone.

Depositional Sequences: Three genetic sequences were identified in each of the two studied Wells. These depositional sequences extended over the interval $7550-5700 \mathrm{ft}$ on well $\mathrm{X}$ and 88325-5550 ft on well Y (Figure 9 and 10). Correlation across the two wells indicate that part of some sequences are not all represented in the wells.
Sequence 1: The first sequence (sequence 1) is bounded at the base by sequence boundary 1 (SB1) which was dated 17.7 Million years (Ma) and at the top by SB2 dated 16.7 Ma and extends from the base on Well X (7550 ft) to $6730 \mathrm{ft}$ and has a thickness of about $820 \mathrm{ft}$ and also from the base on Well Y 8870 to 7400 $\mathrm{ft}$ and has a thickness of about $2140 \mathrm{ft}$ (Figure 9 and 10). This sequence contained the three major systems tracts; LST, TST, HST. The first Lowstand system tract (LST) was identified at depth interval of $7500 \mathrm{ft}$ on well $\mathrm{X}$ and $8750 \mathrm{ft}$ on Well $\mathrm{Y}$ and was characterized by a coarsening upward sequence or a progradational stacking pattern which was recognized by a blocky gamma ray signature. The LST of this sequence in Well Y formed thick sand deposits deposited in the Middle to Outer Neritic depositional settings. The LST was observed to overlie the $17.7 \mathrm{Ma}$ SB and underlie a TST of about $230 \mathrm{ft}$ thick on well $\mathrm{X}$ and $370 \mathrm{ft}$ thick on Well Y. The TST graded into a major condensed section within the MFS which is mainly made up of shale. The TST represents a period of relative rise in sea level when marine flooding across the shelf took place. During this period, relative sea level rise outpaced deposition, thus resulting in sediment starvation. Fining upward sediments in inner neritic to bathyal environments characterized this deposit with the maximum flooding surface marking the end of this systems tract. This maximum flooding surface corresponds to the marker specie Cassigerinella 1 which was dated $17.4 \mathrm{Ma}$. The Highstand systems tracts occured at a depth interval of (7200-6730 ft) on Well X and 8235-7950 ft on Well Y. The HST has units of sand interbedded by shale. The HST fines up to the top into an erosional truncation (sequence boundary) at the depth of $6730 \mathrm{ft}$ on Well $\mathrm{X}$ and 8235 $\mathrm{ft}$ on Well Y. This HST is characterized by aggrading parasequence stacking pattern developed during late relative sea-level rise and highstand of sea level. The HST is associated with shales/sandy and sandstone and terminates with blocky sand at $6650 \mathrm{ft}$ on Well $\mathrm{X}$ and $7400 \mathrm{ft}$ on Well Y. The inferred water depth of the HST is shallow inner neritic. The upper boundary of this HST marks the unconformity surface (sequence boundary).

Sequence 2: Sequence 2 lies conformably on sequence I. The base of sequence II (7400 ft) coincided with the top of sequence 1 and commenced with the Lowstand system tract (LST) from 6700-6590 ft in Well X and 7400 to $6920 \mathrm{ft}$ in Well Y (Figure 9 and 10). The top is a transition from upward shallowing to upward deepening into overlying TST. The interval is characterized by the upward coarsening sands deposited in the shoreface and grades into deeper hemapelagic shale. This TST is characterized by upward fining (backstepping) parasequence stacking pattern deposited during a relative sea level rise. High faunal and floral abundance and diversity characterized this TST. The maximum flooding 
surface (MFS 2) marks the end of this genetic sequence and has been recognized at a depth interval of $6520 \mathrm{ft}$ in Well $\mathrm{X}$ and $6483 \mathrm{ft}$ in Well Y within the F9500 zone. This surface was dated using the regional marker Chiloguembelina 3. The HST located at 6430 $\mathrm{ft}$ in Well X and $6550 \mathrm{ft}$ in Well Y overlies the MFS. The top of the interval is characterized by flooding surface. The HST deposits are aggradational and the interval shows coarsening and shallowing upward and shale interbeds. The inferred paleodepth is MiddleOuter Neritic (MN-ON). This sequence is of Middle Miocene in age.

Sequence 3: This is the topmost (youngest) sequence in the studied wells (Well $\mathrm{X}$ and Well Y). This sequence lies immediately above sequence 2 . It began with the LST which progrades upward from the top of sequence 2. It is made up of thick sandy unit underlain by thin shaly intercalation in both wlss. The sequence consists of thick sand units at its base, deposited during relative sea level fall. This sequence was deposited within the Neritic paleodepositional environment. The sandstone units are individually progradational with coarsening upward stacking pattern towards the MFS in well $\mathrm{X}$ at the depth of $6100 \mathrm{ft}$.

The TST $(6050 \mathrm{ft})$ in Well Y only is made up of several sandy units interbedded by thin shale intercalations. The upper section fines gradually upward and changed into shaly condensed section associated with the MFS at $5830 \mathrm{ft}$ in Well $\mathrm{Y}$ and also occurred at a depth of $6100 \mathrm{ft}$ in well X. This systems tract was not identified in Well X probably due to erosion which must have eroded it from the stratigraphic record. The TST terminates at $5830 \mathrm{ft}$ in Well Y being the Maximum Flooding Surface (MFS) for this sequence. The MFS is dated 15.0 Ma using the according to the Niger Delta chronostratigraphic chart (SPDC, 2009). The HST began with a gradational stacking pattern and finally coarsens upward. The HST consists of sandy units with shale intercalations. This systems tract occurred over the interval

(6100-5700 ft) in Well $\mathrm{X}$ and

(5830-5550 ft) in Well Y.

Exploration Implication of Well $X$ and Well $Y$ : The mapping of key petroleum system enables us to select high-quality prospects, such as those associated with the shelfal lowstand system tract and highstand system tract. The shelfal reservoir sand tends to be best developed in shallow inner neritic water depths. The hemipelagic to pelagic shales of the transgressive system tracts of the study area are also excellent source rock. Thus, all the thick shales in the transgressive system tracts in well $\mathrm{X}$ and well $\mathrm{Y}$ have potential to be excellent source rock. Furthermore, potential reservoirs delineated in Well $\mathrm{X}$ and Well $\mathrm{Y}$ were mainly the channel sands and shoreface sands of LSTs and HSTs respectively, that displayed low gamma ray and high resistivity values.

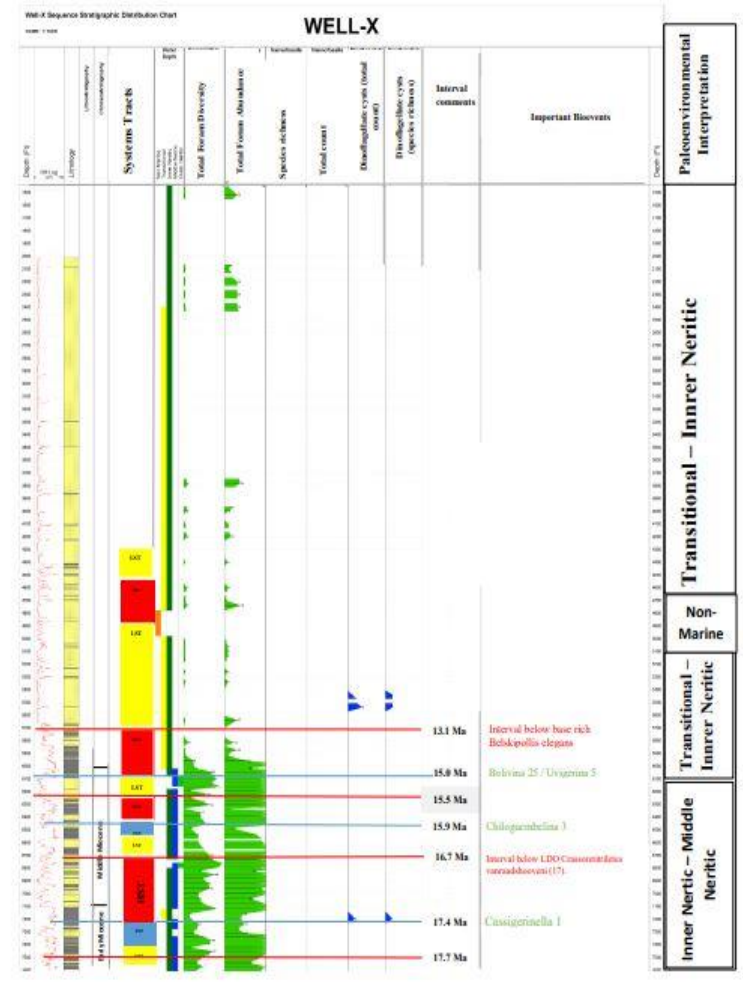

Fig 9: Sequence Stratigraphic Analysis Chart of Well X

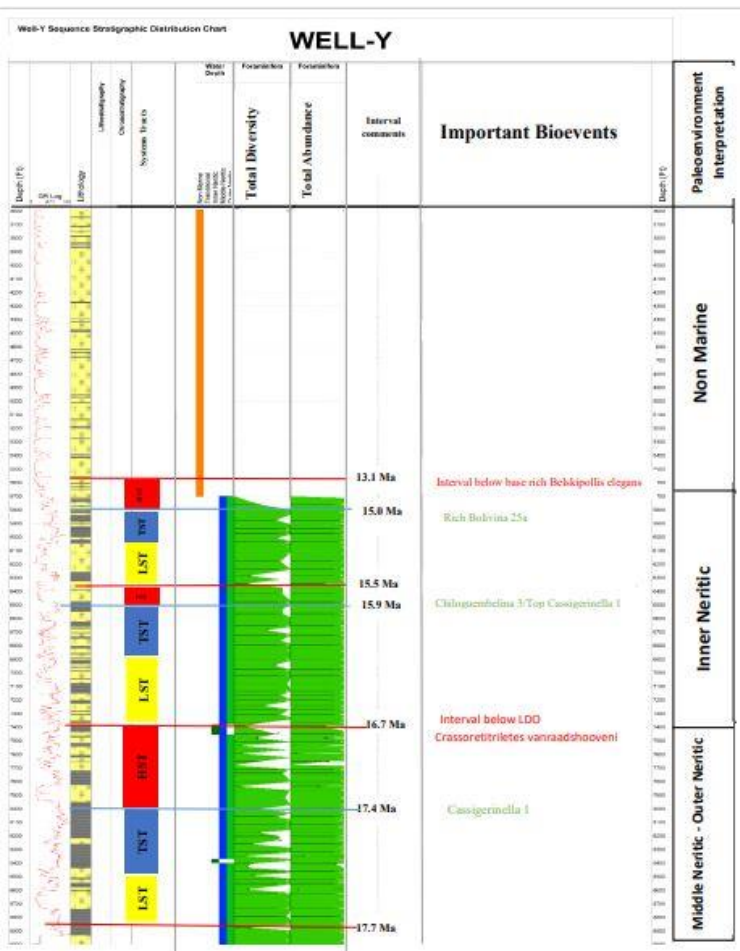

Fig 10: sequence stratigraphic analysis chat of well $Y$ Key to Chart Well X and Well Y:m

- Maximum Flooding Surface - Sequence Boundary 
Conclusion: The delineation and correlation of sequence stratigraphic surfaces enable us to build an approximate chronostratigraphic framework, which is essential for determining facies relationships. In terms of hydrocarbon exploration, the sand units of the LST and HST formed the basin floor fans, channel and shoreface sands of the delta. The high resistivity log values revealed that they are potential good hydrocarbon reservoirs. The shales of the TST in which most of the MFS were delineated could form seals to the reservoir units. A combination of the reservoir sands of the LST and HST and the shale units of the TST can form good petroleum system for hydrocarbon and hence should also be targeted during hydrocarbon exploration. The foraminiferal biozones as well as the palynological biozones unanimously revealed that the age of the studied section of the Well ranged from Early Miocene (Burdigalian) to Middle Eocene (Seravillian). Therefore, a sequence stratigraphic approach is a preferred technique that could lead to a purposeful exploration for hydrocarbon traps especially the stratigraphic types even in the frontier areas with limited well control for enhanced petroleum reserves in the delta.

\section{REFERENCES}

Abraham, CU; Clement, EB; Anietie EE and Monday, UU: (2020): Sequence stratigraphic study of ' $\mathrm{X}$ ' field in eastern offshore of Niger Delta, Nigeria. J. Geo. Mining Res. 12(2): 65-79

Armentrout, JM; Clement J (1993): Biostratigraphic calibration of depositional cycles; A case study In High Island Galveston-East break Addition, Offshore Texas, in; sequence stratigraphy as an exploration tool;. Houston: Elsevier. pp. 50-76.

Cant, D. (1992): Subsurface facies analysis: In Facies Models: Response to Sea Level Change. Geological Association of Canada. pp.45-78.

Catuneanu, O. (2006): Principles of Sequence Stratigraphy. Kidlington, Oxford, UK: Elsevier.

Christie-Blick, N. (1991): Onlap, offlap, and the origin of unconformity bounded depositional sequences, 97, pp. 35-56.

Doust, H., \& Omatsola, E. (1989): Niger Delta. AAPG Memoir, pp. 201-238.
Emery, D \& Myers, KJ; (1996): Sequence stratigraphy. Blackwell Science Limited, 297pp

Evamy, BD., Haremboure, J., Kamerling, P., Knaap, WA., Molloy, FA., \& Rowlands, PH. (1978). Hydrocarbon habitat of Tertiary Niger Delta. AAPG Bulletin 62, pp. 1-39.

Haq, BU., Hardenbol, J., \& Vail, PR. (1988). "Mesozoic and Cenozoic Chronostratigraphy and cycles of sea-level change". (C. H. Wilgus, Ed.) Sea-level Changes: An Integrated Approach SEPM Special Publication, 42, pp. 72-108.

Reijers, TR (2011): Stratigraphy and sedimentology of the Niger Delta. Geologist, 17(3), 133-162.

Rider, MH (1990): Gamma Ray log shape used as a facies indicator. London: Geological Society of London Special Publication Classics. pp. 67-83.

Sprague, AR., Hill, RE., Patterson, PE and Campion, CR;. (2002). The Physical Stratigraphy of Fluvial Strata: A Hierarchical Approach to the Analysis of Genetically Related Stratigraphic Elements for Improved Reservoir Prediction. AAPG Annual Meeting, (pp. 44-57).

Vail, PR. (1987): Seismic stratigraphy interpretation using sequence stratigraphy. Part I: Seismic stratigraphy interpretation procedure. In Atlas of Seismic Stratigraphy, ed. AW Bally, pp. 1-10. Am. Assoc. Petrol. Geol. Stud. Geol. 27, 1. 125

Vail, PR. \& Wornardt, JR; (1992): Well log-seismic sequence stratigraphy, course notes behalf of Global Geotechnical \& Mosunmolu limited, November 26-28th 1992, Lagos, Nigeria, 490 pp.

Van Wagoner, JC; Posamentier, HW; Mitchum, RM Jr; Vail, PR and Sarg, JF (1988); An overview of the fundamentals of sequence stratigraphy and key definitions. See Wilgus et al 1988, pp. 39-45

Whiteman A. (1982). Nigeria: its petroleum geology, resources and potential. London: Graham and Trotman. pp. 54-71 